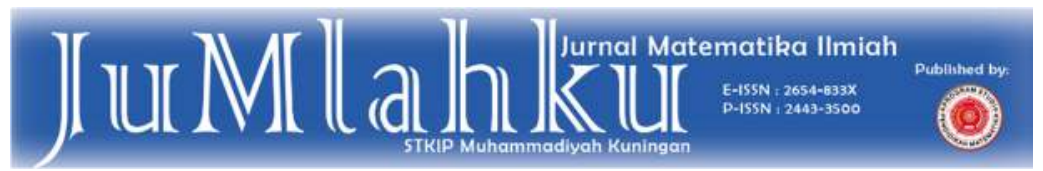

Submited: 2021-10-29

Published: 2021-11-28

\title{
MENINGKATKAN NUMERASI MATEMATIKA MELALUI MODEL PEMBELAJARAN KOOPERATIF TEKNIK TEAMS GAMES TOURNAMENT (TGT)
}

Topic Offirstsona), Reza Muhamad Zaenal ${ }^{\text {b) }}$

a MTs Negeri 1 Kuningan, Jawa Barat

b STKIP Muhammadiyah Kuningan, Jawa Barat

Corresponding Author : topicoffirstson@yahoo.com a)

rezamz@upmk.ac.id b)

Article Info

Keywords : Numeracy,

Cooperative Model, Teams

Games Tournament (TGT)
Kata Kunci: Numerasi, Model Kooperatif, Teams Games Tournament (TGT)
This research is a Classroom Action Research (CAR) which aims to improve the numeracy skills of class VII students on social arithmetic material by using a team games tournament (TGT) technique cooperative learning model. The subjects of this study were 32 students of class VII C MTs Negeri 1 Kuningan. Data collection techniques in this study were observation, interviews and tests of students' numeracy skills. This research was conducted in two cycles, because in the first cycle it had not reached the expected completeness or indicators. The results of the research in the precycle showed that students' numeracy skills had an average of 21 with a learning completeness percentage of $0 \%$, after being given action in the first cycle using the Team Games Tournament (TGT) cooperative learning model, they experienced an increase in numeracy skills with an average value of 62 and the percentage of students' completeness is 59\%, but the research has not yet achieved success, then it is continued with cycle II. The average value of students' numeracy abilities after the second cycle was 74 with a completeness percentage of $78 \%$, so it can be concluded that the team games tournament (TGT) cooperative learning model can improve students' numeracy skills.

Penelitian ini merupakan Penelitian Tindakan Kelas (PTK) yang bertujuan untuk meningkatkan kemampuan numerasi siswa kelas VII pada materi aritmatika sosial dengan menggunakan model 
pembelajarn kooperatif teknik teams games tournament (TGT). Subjek penelitiaan ini adalah 32 siswa kelas VII C MTs negeri 1 Kuningan. Teknik pengumpulan data pada penelitian ini adalah observasi, wawancara dan tes kemampuan numerasi siswa. Penelitian ini dilakukan dalam dua siklus, karena pada siklus pertama belum mencapai ketuntasan atau indikator yang diharapkan. Hasil penelitian pada pra siklus menunjukan kemampuan numerasi siswa mempunyai rata-rata 21 dengan persentase ketuntasan belajarr $0 \%$, setelah diberikan tindakan pada siklus I dengan menggunakan model pembelajarn kooperatif teknik teams games tournament (TGT) mengalami peningkatan kemampuan numerasi dengan nilai rata-rata 62 dan persentase ketuntasan siswa 59\%, tetapi belum mencapai keberhasilan penelitian maka dilanjutkan dengan siklus II. Nilai ratarata kemampuan numerasi siswa setelah dilakukan siklus II adalah 74 dengan persentase ketuntasan $78 \%$, sehingga dapat disimpulakn bahwa model pembelajaran kooperatif teknik teams games tournament (TGT) dapat meningkatkan kemampuan numerasi siswa.

\section{PENDAHULUAN}

Ketika kita pergi ke pasar, kita membawa cukup uang untuk berbelanja, tetapi tidak tahu cara menghitung uang untuk berbelanja atau kita mempunyai sebidang tanah yang akan dijual, tetapi tidak tahu kisaran harga tanah dan tidak bisa mengukur tanah tersebut, padahal tanah itu dijual menggunakan ukuran. Itu merupakan salah satu contoh kemampuan numerasi sederhana dalam kehidupan sehari-hari. Penting bagi setiap individu untuk mengetahui dan memahami perannya matematika dalam kehidupan nyata sehingga individu mampu menggunakan ilmu dalam matematika untuk kehidupan sehari-hari dengan baik (Rizki \& Priatna, 2019). Keterampilan ini disebut keterampilan literasi matematika atau kemampuan numerasi .

50
Menurut Cohen, kemampuan numerasi yang rendah mempunyai dampak yang negatif pada prospek kerja, mental, fisik, kesehatan dan ekonomi individu dan negara (Cohen Kadosh et al., 2013). Maka perlunya peningkatan numerasi di semua kalangan, tertutama siswa sekolah dasar yang menjadi prioritas utama. Mengapa harus sekolah dasar, karena menurut Riikka Mononen dalam penelitiannya mengatakan bahwa intervensi dini untuk anak berusia 47 tahun beresiko mengalami kesulitan dalam menghubungkan matematika dengan kehidupan sehari-hari (Mononen et al., 2014). Maka perlu dibiasakan dengan numerasi dari sejak dini, supaya hal tersebut bisa dihindari.

Numerasi bukan sesuatu yang baru, pertama kali diperkenalkan tahun 1959 oleh pemerintah Inggris (Kementerian 
Pendidikan dan Kebudayaan, 2017). Numerasi merupakan bagian dari matematika, walaupun tidak terdefinisi dalam bagian tertentu dalam matematika. Numerasi dapat diartikan sebagai kemampuan untuk mengaplikasikan konsep bilangan dan keterampilan operasi hitung di dalam kehidupan sehari-hari dan kemampuan untuk menginterpretasi informasi kuantitatif yang terdapat di sekeliling kita (Anam et al., 2020).

Jika kita melihat hasil PISA terakhir tahun 2018 yang salah satunya mengukur numerasi, siswa di Indonesia mendapat nilai lebih rendah dari rata-rata OECD dalam membaca, matematika dan sains (OECD, 2019), Hal ini sangat memprihatinkan karena kemampuan numerasi adalah pijakan awal bagi anak-anak dalam belajar matematika disekolah (Aunio, 2019). Keterampilan numerasi akan memediasi efek motivasi prestasi matematika di jenjang berikutnya (Mercader et al., 2018).

Kemampuan numerasi akan memberikan banyak keuntungan dan efek bagi perkembangan siswa, jika pembelajarannya dilakukan setiap minggu (Dowker, 2017). Maka perlunya pembelajaran numerasi walaupun di masa pendemi untuk meningkatkan kemampuan numerasi matematika. Pentingnya strategi untuk meningkatkan kemampuan leterasi dan numerasi untuk pembelajaran dan kehidupan (Department of Education and Skills, 2017).

Asesmen kompetensi minumum (AKM) adalah program baru pemerintah untuk menguji kelayakan peserta didik dalam bidang numerasi dan literasi. Hal ini bisa terlihat begitu pentingnya kemampuan literasi ini, yang jadi pertanyaan apakah siswa kita sudah siap dengan AKM ini?, apakah di sekolah sudah ada pembelajaran tentang numerasi?, apakah siswa senang ketika belajar numerasi matematika?. Perlu adanya pembelajaran yang menarik bagi siswa, untuk meingkatkan numerasi. ha ini sejalan dengan apa yang disampaikan Miller dalam penelitiannya, siswa akan lebih tertarik kepada sesuati yang menarik dalam pembelajaran jika dibandingkan dengan sesuatu yang tidak menarik tapi berkualitas (Miller, 2018). Maka diperlukannya sebuah model yang membuat siswa tertarik dan menyenangkan.

Teams Games Tournament (TGT) adalah salah satu teknik dalam model pembelajaran kooperatif, anak akan senang ketika belajar dengan teknik ini karena mereka akan diajak permainan kelompok tetapi sambil belajar. Menurut Mulyani dkk (Mulyani et al., 2018) model pembelajaran kooperatif teknik Teams Games Tournament (TGT) merupakan model pembelajaran kooperatif dimana kegiatan belajar siswa diawali dengan memperhatikan penjelasan guru di depan kelas (presentasi kelas), 
teams (belajar kelompok), games (memainkan permainan), kemudian tournament (turnamen akademik) dan terakhir evaluasi tim. Hal ini memberikan kesempatan belajar bagi siswa, karena siswa mempunyai peran yang penting dalam proses pembelajaran, sejalan dengan yang disampaikan Hwang dkk (Hwang \& Ham, 2021) kesempatan belajar dengan tugas prosedural cendrung meningkatkan literasi matematika atau numerasi.

Model pembelajaran teams games tournament (TGT) dapat meningkatkan kreatifitas dan pemahan konsep matematika (Ramadhani \& Indrawati, 2020). Kreatifitas dan pemahaman konsep matematika sangat erat kaitannya dengan kemampuan numerasi, ini bisa menjadi dasar kita untuk diteliti. Model pembelajaran teams games tournament (TGT) mempengaruhi dan meningkatkan aktivitas siswa dan guru di dalam kelas (Apriani et al., 2014). Dalam pembelajaran di kelas, aktivitas guru akan lebih dominan dibandingkan siswa, tetapi dalam model pembelajaran Teams Games Tournament (TGT), aktivitas siswa dan guru akan seimbang, jadi siswa akan memiliki peran yang sama dengan guru.

Salam dkk (Salam et al., 2015) dalam penelitiannya menyebutkan bahwa teknik teams games tournament (TGT) memebrikan dampak positif bagi sikap siswa terhadap matematika jika dibandingkkan dengan teknik konvensional. Model 52 pembelajaran kooperatif tipe teams games tournament (TGT) bisa menjadi solusi dalam meningkatkan kemampuan numerasi siswa untuk menghadapi asesmen kompetensi minimum. Kemudian menurut Veloo (Veloo et al., 2016) bahwa teams games tournament (TGT) memebrikan efek yang signifikan pada pemahaman dan komunikasi matematika. Teams games tournament (TGT) akan menjadikan kelas menjadi ramai, hal ini membuat siswa tertarik untuk belajar. Seperti halnya yang disampaikan oleh Baydar (Baydar, 2020) perlu adanya kelas yang ramai dan hidup untuk membuat siswa betah di kelas untuk belajar.

Berdasarkan latar belakang di atas, tujuan penelitain ini adalah untuk menegetahui apakah model pembelajaran kooperatif tipe teams games tournament (TGT) dapat meningkatkan kemampuan numerasi.

\section{METODE}

Penelitain ini adalah Penelitian Tindak Kelas yang bertujuan untuk meningkatkan mutu dan kualitas pemebelajaran di kelas, baik pada siswa ataupun gurunya sendiri. Adapun model Penelitian Tindak Kelas (PTK) yang digunakan dalam penelitian ini adalah model PTK Kurt Lewin yang merupakan model Penelitian Tindak Kelas (PTK) yang pertama kali ada dengan menggunakan 4 langkah dalam proses penelitian. Langkah-langkah model 
Penelitian Tindak Kelas (PTK) Kurt Lewin yaitu perencanaan, tindakan atau pelaksanaan, pengamatan dan refleksi.

Sasaran atau subjek dalam Penelitian Tindak Kelas (PTK) adalah siswa kelas VII C MTS Negeri 1 Kuningan yang terdiri dari 13 siswa laki-laki dan 19 siswa perempuan, jadi ada 32 siswa sebagai subjek Penelitian Tindak Kelas (PTK) ini. Penelitian Tindak Kelas (PTK) ini agak berbeda dengan Penelitian Tindak Kelas (PTK) yang umum dilakukan, karena Penelitian Tindak Kelas (PTK) dilakukan dua gelombang, hal ini dikarenakan penelitian ini dilakukan di masa pandemi covid-19 yang hanya memperbolehkan pembelajaran tatap muka hanya $50 \%$ dari jumlah siswa dalam kelas. Tetapi ini tidak mengurangi esensi dan hasil dari Penelitian Tindak Kelas (PTK) ini. Untuk waktu penelitian dilaksanakan dari tanggal 1 Februari - 27 Februari 2021.

Teknik pengumpulan data dalam penelitian ini adalah teknik wawancara dan tes. Wawancara dilakukan diawal penelitian, yaitu dengan mengidentifikasi permasalah dalam pembelajaran yang dirasakan oleh guru dan berupaya untuk mencari solusinya. Kemudian untuk teknik tes digunakan untuk mengukur tingkat keberhasilan pembelajaran setelah diberi tindakan dari setiap siklus yang dilakukan.

Untuk mengukur tingkat keberhasilan Penelitian Tindak Kelas (PTK) dalam penelitian ini dilihat dari tiga aspek, jika ketiga aspek tersebut terpenuhi maka penelitian dinyatakan berhasil. Ketiga aspek tersebut yaitu: 1) Pembelajaran dengan menerapkan model pembelajaran Teams Games Tournament (TGT) dikatakan berhasil jika setelah dilakukan tindakan terdapat peningkatan hasil belajar siswa sebesar $\geq 75 \%$. 2) Aspek keberhasilan dalam Penelitian Tindak Kelas (PTK) ini adalah tercapainya $75 \%$ siswa mendapat nilai 65 atau lebih. 3) Hasil belajar matematika dikatakan berhasil apabila nilai evaluasi di atas atau sama dengan $75 \%$ (Sidi \& Yunianta, 2018).

\section{HASIL DAN PEMBAHASAN}

Penelitian Tindak Kelas (PTK) ini diawali dengan tahap observasi yaitu peneliti mulai melakukan observasi, pada kegiatan observasi ini peneliti melakukan identifikasi masalah yang ada dalam kelas sampai kepada mencari solusi permasalah tersebut. Permasalahan yang diobservasi tersebut mencakup permasalahan yang menghambat peningkatan hasil belajar siswa. Peneliti melakukan wawancara dengan siswa dan guru MTs Negeri 1 Kuningan, kemudian melihat hasil ulangan harian siswa dan nilai ujian akhir semester untuk mengetahui masalah yang menyebabkan hasil belajar matematika siswa tidak memuasakan. Dari data yang didapat, nilai 26 siswa dari 32 siswa kelas VII $C$ belum mencapai KKM, jadi hanya 6 siswa 
yang sudah mencapai KKM. Selain itu juga peneliti melakukan tes pra siklus di kelas VII $C$ yang merupakan bagian dari observasi, hasil dari pra siklus dapat dilihat dari gambar 1.

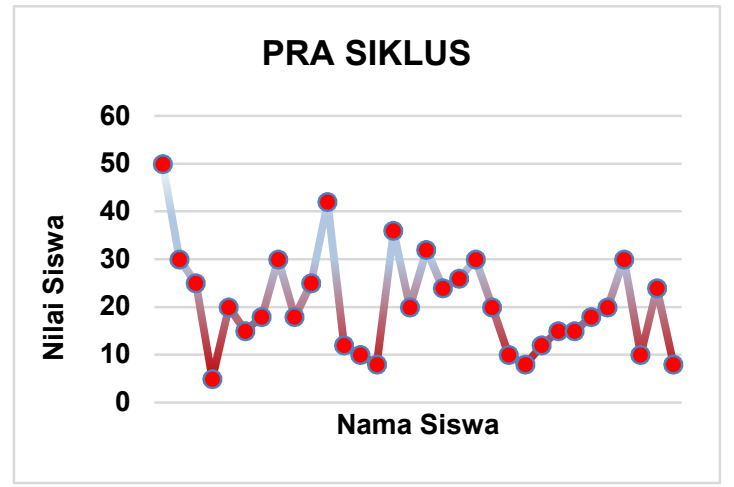

Gambar 1. Data Nilai Numerasi Siswa Kelas VII C

Dari data tersebut dapat dilihat kemampuan numerasi siswa pra siklus secara rinci pada Tabel 1.

Tabel 1 Kemampuan Numerasi Siswa Pra Siklus

\begin{tabular}{|c|c|c|c|c|c|c|c|}
\hline \multirow{2}{*}{$\begin{array}{c}\text { Ju } \\
\text { mla } \\
\text { h } \\
\text { Sis } \\
\text { wa }\end{array}$} & \multirow{2}{*}{$\begin{array}{r}\text { Nila } \\
\text { tingi }\end{array}$} & \multirow{2}{*}{$\begin{array}{l}\text { Nila } \\
\text { i } \\
\text { Ter } \\
\text { end } \\
\text { ah }\end{array}$} & \multirow{2}{*}{$\begin{array}{l}\text { Nila } \\
\text { i } \\
\text { Rat } \\
\text { a- } \\
\text { rata }\end{array}$} & \multicolumn{2}{|c|}{$\begin{array}{l}\text { Siswa } \\
\text { yang } \\
\text { Tuntas }\end{array}$} & \multicolumn{2}{|c|}{$\begin{array}{c}\text { Siswa yang } \\
\text { Tidak } \\
\text { Tuntas }\end{array}$} \\
\hline & & & & $\begin{array}{c}\mathrm{Ju} \\
\mathrm{mla} \\
\mathrm{h}\end{array}$ & $\begin{array}{l}\text { Pre } \\
\text { sen } \\
\text { tasi }\end{array}$ & $\begin{array}{c}\mathrm{Ju} \\
\mathrm{mla} \\
\mathrm{h}\end{array}$ & $\begin{array}{l}\text { Pres } \\
\text { enta } \\
\text { si }\end{array}$ \\
\hline 32 & 50 & 5 & 21 & 0 & $0 \%$ & 32 & $\begin{array}{c}100 \\
\%\end{array}$ \\
\hline
\end{tabular}

Berdasarakan gambar di atas, dari 32 siswa kelas VII C belum ada yang memenuhi $\mathrm{KKM}$, karena siswa belum sama sekali menerima materi aritmatika. Setelah melakukan observasi, tahap selanjutnya adalah tahap pelaksanaan yaitu tahap siklus untuk mencapai aspek atau indikator keberhasilan sebesar $75 \%$ siswa dapat memenuhi nilai KKM. Penelitian ini akan selesai pada saat indikator keberhasilan tercapai.

Adapun penerapan model pembelajaran koopertaif teknik teams games tournament Penelitian Tindak Kelas (PTK) dalam penelitian ini dilakukan dalam empat tahap yaitu sebagai berikut:

\section{Perencanaan}

Tahap awal dalam penelitian ini yaitu tahap perencanaan, dalam tahapa perencanaan ini peneliti merefleksi dan menganalisis masalah yang terjadi di dalam kelas dan proses pembelajaran yang terjadi serta mencari alternatif-alternatif untuk memecahkan masalah tersebut. Dalam tahap perencanaan ini, peneliti melakukan tiga kegiatan utama yaitu: 1) tahap pertama menganalisis kurikulum pembelajaran yang digunakan dalam proses pembelajaran, menganalisis standar kompetensi dan kompetensi dasar serta materi inti yang akan disampaikan dengan model pembelajaran kooperatif teknik teams game tournament; 2) tahap kedua menetapkan indikator ketercapaian hasil belajar matematika siswa 
pada materi aritmatika yang mengacu pada SK dan KD; 3) tahap ketiga merancang dan membuat Rencana Pelaksanaan Pembelajaran (RPP) yang disesuaikan dengan model pembelajaran kooperatif teknik teams game tournament, menyiapkan LKS, menyiapkan sarana dan prasarana pembelajaran, instrumen penilaian dan lembar observasi.

\section{Tindakan atau Pelaksanaan}

Pada tahap ini peneliti mulai menerpakan model pembelajaran koperatif teknik teams game tournament sesuai dengan RPP yang telah dibuat pada tahap perencanaan, dengan model pembelajaran ini diharapkan dapat meningkatkan kemampuan numerasi matematika siswa. Tindakan dilakukan dalam tiga pertemuan, pada pertemuan pertama dimulai dengan pendahuluan yaitu tujuan pembelajaran yang akan dicapai pada pembelajran aritmatikadan menjelaskan kepada peserta didik terkait pelajaran yang akan dilakukan dalam tiga pertemuan kedepan.

Kegiatan selanjutnya adalah kegiatan inti dari teams game tournament yaitu dimulai dengan penyajian kelas dimana dalam tahap ini guru memberikan pembelajaran dengan metode ceramah, dengan memberikan materi aritmatika dengan contoh-contoh soalnya. Kemudian setelah diberikan materi secara garis besar siswa dibagi menjadi 6 kelompok yang terdiri dari 4-6 siswa perkelompok, untuk sistem pembagian kelompoknya sendiri dilakukan secara merata, dimana kemampuan dari setiap anggota kelompok beragam.

Setelah siswa dibagi kedalam 6 (enam) kelompok maka dimulailah game yaitu setiap kelompok diberi beberapa soal yang harus dikerjakan, pada tahap ini siswa yang sudah paham materi memberikan penjelasan kepada siswa yang masih belum memahami materi. Setelah semua kelompok menyelesaikan tugas yang telah diberikan guru, setiap kelompok mempresentasikan hasilnya didepan kelas, kemudian guru memberikan hasil penilaiannya.

Setelah games selesai, selanjutnya adalah tahap tournament dimana pada tahap ini setiap kelompok mendelegasikan satu anggotanya untuk bertanding dengan kelompk lain yang mempunyai kemampuan setara dalam satu turnamen. Dalam turnamen ini, setiap delegasi kelompok berkompetisi dalam menyelesaikan soal yang diberikan oleh guru untuk mengumpulkan poin sebanyak mungkin untuk kelompok. Setelah semua perwakilan kelompok selesai bertanding, guru akan mengakumulasikan semua nilai atau poin yang telah didapatkan. Kemudian guru mengumumkan pemenangnya serta memberikan penghargaan kepada setiap kelompok berdasarkan pencapaiannya.

Pada pertemuan kedua guru melakukan lanngkah yang sama tetapi 
dengan materi yang berbeda, pada jeda tiap langkah pembelajaran guru juga memberikan motivasi dan permainan matematika supaya anak lebih enjoy dalam belajar. Kemudian dipertemuan selanjutnya dilakukan tes akhir guna mengetahui kemampuan numerasi siswa setelah diterapkan atau diperlakukan model pembelajaran kooperatif teknik teams game tournament (TGT).

\section{Pengamatan atau Observasi}

Kegiatan observasi dilakukan peneliti ketika proses pembelajaran berlangsung yaitu ketika guru memberikan materi menggunakan model pembelajaran kooperatif teknik teams game tournament (TGT), dimana observasi ini dilakukan terhadap guru dan siswa yang terlibat. Adapun hasil observasi dapat dilihat dalam tabel berikut.

\section{Tabel 2. Rekapitulasi Data Hasil} Observasi Siklus I dan II

\begin{tabular}{|c|c|c|c|}
\hline \multirow{2}{*}{$\begin{array}{c}\text { Indeks Hasil } \\
\text { Observasi }\end{array}$} & \multicolumn{2}{|c|}{$\begin{array}{c}\text { Rata-rata } \\
\text { Persentase Setiap } \\
\text { Pertemuan (\%) }\end{array}$} & $\begin{array}{c}\text { Kesimpula } \\
\mathrm{n}\end{array}$ \\
\hline & $\begin{array}{lll}\text { I } & \text { II III }\end{array}$ & $\begin{array}{l}\text { Rata- } \\
\text { rata } \\
(\%)\end{array}$ & \\
\hline
\end{tabular}

Indeks

$\begin{array}{lllll}\text { Observasi } & 6 & 7 & 80 & 72,8\end{array}$ $\begin{array}{lllll}\text { Pembelajara } & 5 & 3 & , 5 & 3\end{array}$ n Guru (IPG)
Indeks

Observasi

Respons

$$
\begin{array}{ll}
7 & 8
\end{array}
$$

$90 \quad 82,6$ 7

Baik Siswa (IRS)

Indeks

Observasi

Kondisi

Lingkungan

$\begin{array}{ccccc}8 & 9 & 93 & 88,3 & \text { Sangat } \\ 2 & 0 & 93 & 3 & \text { Baik }\end{array}$
(IKL)

Tabel hasil observasi di atas menunjukan tren yang positif dari hasil observasi lapngan terhadap pembelajaran guru, respons siswa dan kondisi lingkungan. Dari tabel tersebut menunjukan bahwa Indeks Pembelajaran Guru (IPG) mendapatkan respon baik dengan rata-rata $72,83 \%$, kemudian untuk Indeks Respons Siswa (IRS) terhadap pembelajaran yang dilakukan mendapatkan rata-rata 82,67 dan Indeks Kondisi Lingkungan (IKL) mendatkan rata-rata 88,33. Dengan demikian dapat disimpulakn bahwa hasil observasi dalam rangka penelitian PTK dengan model pembelajaran kooperatif teams game tournament (TGT) mendapatkan hasik baik.

\section{Refleksi}

Kegiatan refleksi dilakukan peneliti ketika tindakan dan observasi selesai dilaksanakan. Pada tahap ini peneliti menganalisis hasil dari observasi terhadap guru dan siswa yang terlibat dalam pembelajaran, bagaimana proses belajar 
mengajar dalam kelas, respon siswa terhadap pembelajaran. Observasi ini menjadi salah satu indikator untukeberhasilan pembelajaran teams game tournament dan menganalisis hasil tes akhir untuk mengetahui apakah model pembelajaran kooperatif teknik teams game tournament (TGT) dapat meningkatkan kemampuan numerasi siswa kelas VII C MTs Negeri 1 Kuningan. Jika pada hasil refleksi tidak sesuai dengan indikator keberhasilan yang telah ditetapkan maka dilakukan perbaikan pembelajaran untuk dilaksanakan pada siklus selanjutnya.

Hasil tek akhir kemampuan numerasi setelah dilakukukan tindakan pada siklus I dengan menggunakan model pembelajaran kooperatif teknik teams game tournament (TGT) dapat dilihat dari gambar 2 berikut ini:

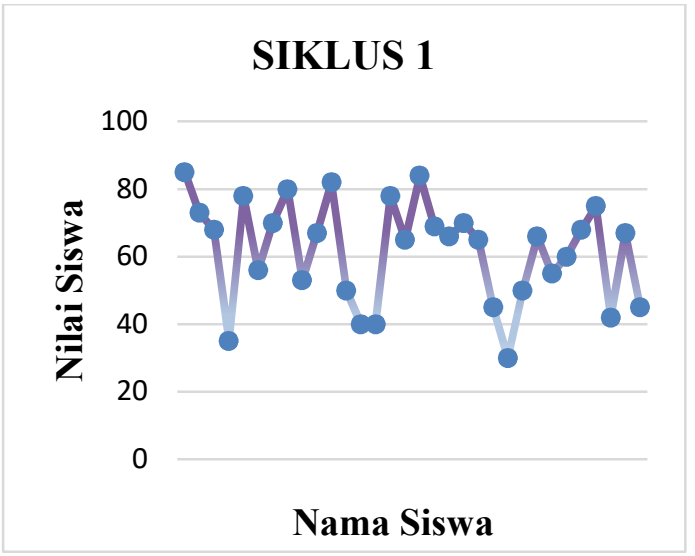

Gambar 2. Nilai Numerasi Siklus I
Dari gambar di atas dapat dilihat kemampuan numerasi siswa melalui secara rinci dari Tabel 3.

Tabel 3 Kemampuan Numerasi Siklus I

\begin{tabular}{|c|c|c|c|c|c|c|c|}
\hline \multirow{2}{*}{$\begin{array}{l}\text { Juml } \\
\text { ah } \\
\text { Sisw } \\
\text { a }\end{array}$} & \multirow{2}{*}{$\begin{array}{l}\text { Nila } \\
\text { i } \\
\text { Ter } \\
\text { ting } \\
\text { gi }\end{array}$} & \multirow{2}{*}{$\begin{array}{l}\text { Nila } \\
\text { i } \\
\text { Ter } \\
\text { end } \\
\text { ah }\end{array}$} & \multirow{2}{*}{$\begin{array}{l}\text { Nila } \\
\text { i } \\
\text { Rat } \\
\text { a- } \\
\text { rata }\end{array}$} & \multicolumn{2}{|c|}{$\begin{array}{c}\text { Siswa } \\
\text { yang } \\
\text { Tuntas }\end{array}$} & \multicolumn{2}{|c|}{$\begin{array}{c}\text { Siswa } \\
\text { yang } \\
\text { Tidak } \\
\text { Tuntas }\end{array}$} \\
\hline & & & & $\begin{array}{c}\mathrm{Ju} \\
\mathrm{mla} \\
\mathrm{h}\end{array}$ & $\begin{array}{l}\text { Pre } \\
\text { sen } \\
\text { tasi }\end{array}$ & $\begin{array}{c}\mathrm{Ju} \\
\mathrm{mla} \\
\mathrm{h}\end{array}$ & $\begin{array}{l}\text { Pre } \\
\text { sen } \\
\text { tasi }\end{array}$ \\
\hline 32 & 85 & 30 & 62 & 19 & $\begin{array}{r}59 \\
\%\end{array}$ & 13 & $\begin{array}{l}31 \\
\%\end{array}$ \\
\hline
\end{tabular}

Berdasarkan Tabel 3 di atas dapat disimpulkan bahwa kemampuan numerasi siswa kelas VII C belum mencapai indikator keberhasilan yang diharapkan yaitu $75 \%$ siswa yang tuntas. Dari 32 siswa yang mengikuti tes, baru 19 siswa yang memenuhi kriteria ketuntas yaitu lebih dari 65 dengan presentase $59 \%$, sedangkan presentase yang diharapkan sesuai indikator adalah $75 \%$. Karena tidak memenuhi indikator yang telah ditentukan maka peneliti melakukan tindakan untuk siklus kedua, adapun untuk hasil tindakan dilakukan sama halnya seperti proses pada tindakan pertama, yaitu dimulai dengan perencana dan diakhiri dengan refleksi atau tes akhir. Untuk hasil tes akhir kemampuan numerasi siklus II dapat dilihat pada Gambar 3. 


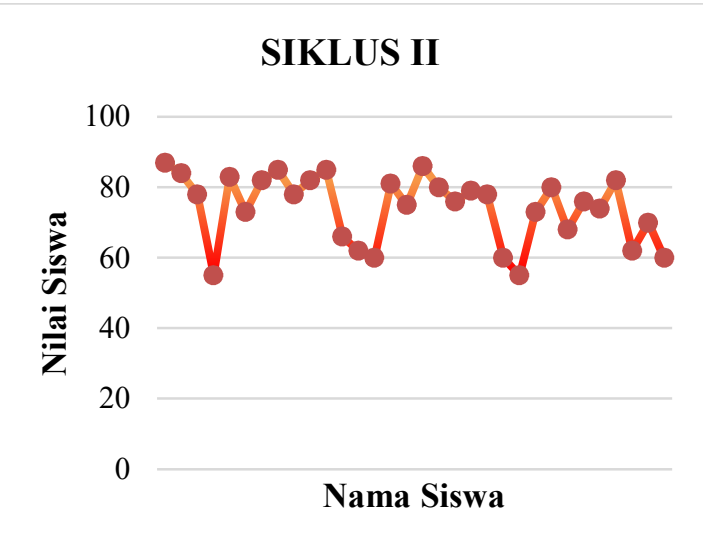

Gambar 3 Nilai Numerasi Siklus II

Dari gambar di atas dapat dilihat kemampuan numerasi siswa setelah siklus II secara rinci dapat dilihat pada tabel Tabel 4 .

Tabel 4 Kemampuan Numerasi Siklus II

\begin{tabular}{|c|c|c|c|c|c|c|c|}
\hline \multirow{2}{*}{$\begin{array}{c}\text { Juml } \\
\text { ah } \\
\text { Sisw } \\
\text { a }\end{array}$} & \multirow{2}{*}{$\begin{array}{c}\text { Nila } \\
\text { i } \\
\text { Ter } \\
\text { ting } \\
\text { gi }\end{array}$} & \multirow{2}{*}{$\begin{array}{c}\text { Nila } \\
\text { i } \\
\text { Ter } \\
\text { end } \\
\text { ah }\end{array}$} & \multirow{2}{*}{$\begin{array}{c}\text { Nila } \\
\text { i } \\
\text { rata } \\
- \\
\text { rata }\end{array}$} & \multicolumn{2}{|c|}{$\begin{array}{c}\text { Siswa } \\
\text { yang } \\
\text { Tuntas }\end{array}$} & \multicolumn{2}{|c|}{$\begin{array}{c}\text { Siswa } \\
\text { yang } \\
\text { Tidak } \\
\text { Tuntas }\end{array}$} \\
\hline & & & & $\begin{array}{c}\mathrm{Ju} \\
\mathrm{mla} \\
\mathrm{h}\end{array}$ & $\begin{array}{l}\text { Pre } \\
\text { sen } \\
\text { tasi }\end{array}$ & $\begin{array}{c}\mathrm{Ju} \\
\mathrm{mla} \\
\mathrm{h}\end{array}$ & $\begin{array}{l}\text { Pre } \\
\text { sen } \\
\text { tasi }\end{array}$ \\
\hline 32 & 87 & 55 & 74 & 25 & $\begin{array}{r}78 \\
\%\end{array}$ & 7 & $\begin{array}{r}22 \\
\%\end{array}$ \\
\hline
\end{tabular}

Berdasarkan tabel di atas dapat disimpulkan bahwa kemampuan numerasi siswa kelas VII C sudah mencapai indikator keberhasilan yang diharapkan yaitu $75 \%$ siswa yang tuntas. Dari 32 siswa yang mengikuti tes, 25 siswa telah dinyatakan tuntas dengan nilai lebih dari 65 , persentase siswa yang sudah tuntas adalah $78 \%$. Sedangkan terdapat 7 siswa yang masih belum tuntas, dengan persentase $22 \%$.

Sebelum peneliti melakukan penelitian, terlebih dahulu dilakukan tes sebelum diberikan perlakuan teams games tournament (TGT), dari hasil Pra Siklus tersebut belum ada siswa yang mencapai KKM dengan nilai tertinggi 50 . Setelah siswa diberikan perlakuan, yaitu belajar dengan model pembelajaran teams games tournament (TGT) terlihat adanya peningkatan jika dilihat dari hasil tes siklus I, pada hasil siklus I terdapat 19 siswa yang sudah mencapai nilai KKM atau sekitar $59 \%$ siswa yang sudah memperoleh nilai di atas KKM. Hasil siklus I belum bisa mencapai keberhasilan dalam penelitian tindakan kelas, maka dari itu peneliti melakukan siklus II untuk meningkatkan kemampuan numerasi siswa. Dari hasil siklus II didaptkan bahwa dari 32 siswa yang mengikuti tes kemampuan numerasi pasca tindakan kelas siklus II ada 25 siswa yang dinyatakan lulus dan mendapatkan nilai di atas KKM atau sekitar $78 \%$ siswa telah lulus.

Hasil ini selaras dengan penelitian terdahulu, yang dilakukan oleh Ramdani dan Indrawati (Ramadhani \& Indrawati, 2020) bahwa model pembelajarn kooperatif teknik teams games tournament (TGT) dapat meningkatkan hasil belajar siswa, dari para 
peneliti terdahulu tersebut menyimpulakn bahwa model pembelajaran kooperatif teknik teams games tournament (TGT) dapat meningkatkan hasil bejar matematika siswa sekolah dasar, walapun yang di tes dalam penelitian ini adalah kemampuan numerasi, perbedaan penelitian ini dengan penelitian terdahalu terletak dari kemampuan yang diujikan, penelitian ini mengujikan kemampuan numerasi siswa, sedangkan penelitian terdahulu lebih kearah hasil belajar matematika.

Hasil penelitian ini sama dengan hasil penelitian yang dilakukan oleh Winaryo dan Himayah (Ramadhani \& Indrawati, 2020) bahwa model pembelajaran kooperatif teknik teams games tournament (TGT) dapat meningkatkan hasil belajar matematika siswa, walapun ada perbedaan antara hasil belajar matematika dan numerasi. Setelah dilakukan penelitian mulai dari pra siklus sampai dengan siklus II menunjukan adanya peningkatan kemampuan numerasi siswa. Peningkatan tersebut terjadi ketika diterapkannya model pembelajaran kooperatif teknik teams games tournament (TGT) pada materi aritmatika. Berikut ini gambar grafik peningkatan dari mulai pra siklus, siklus I dan siklus II.

\section{PRA SIKLUS \& SIKLUS I}

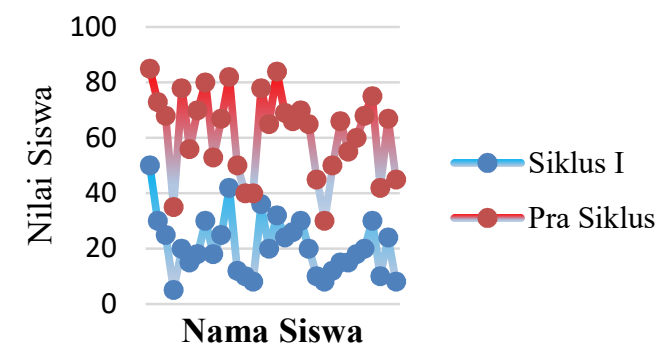

Gambar 4. Grafik Perbandingan Kemampuan Numerasi Siswa pada Pra Siklus dan Siklus I

Berdasarkan grafik di atas terlihat adanya peningkatan kemampuan numerasi siswa kelas VII C Mts Negeri 1 Kuningan, dari grafik tersebut menunjukan bahwa kemampuan numerasi pada pra siklus masih sangat rendah, tidak ada yang mencapai $\mathrm{KKM}$, tetapi setelah siswa belajar dengan model pembelajaran kooperatif teknik teams game tournament (TGT) siswa mengalami peningkatan, seperti data pada grafik siklus I. 


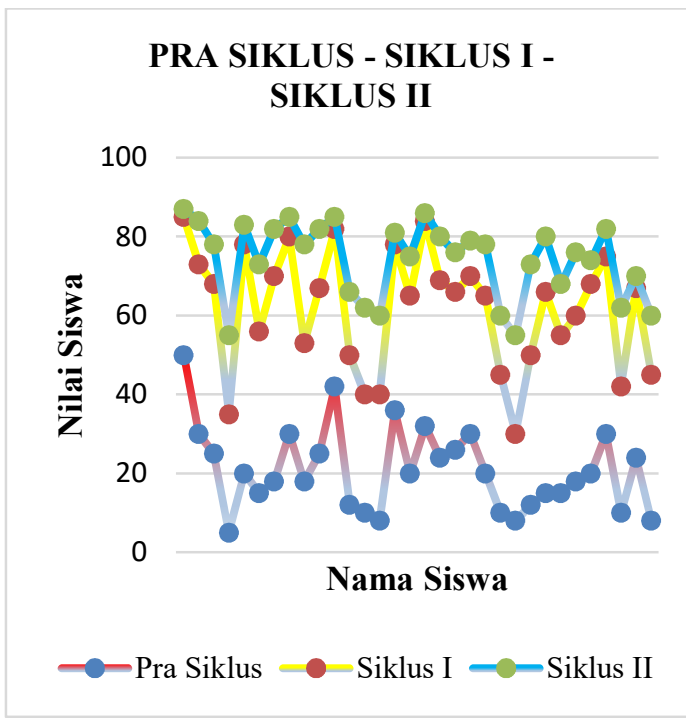

Gambar 5. Grafik Perbandingan

Kemampuan Numerasi Siswa pada Pra

Siklus, Siklus I dan Siklus II

Berdasarkan grafik di atas terlihat adanya peningkatan yang signifikan pada siklus II, jika dibandingkan dengan pra siklus dan siklus I. Hal ini terlihat adanya perbedaan yang kemampuan numerasi siswa setelah dilakukan siklus II, dalam hal ini siklus II adalah pijakan keberhasilan penelitian tindakan kelas, setelah memenuhi syarat ketercapain keberhasilan $75 \%$ siswa telah memenuhi KKM untuk kemampuan numerasinya. Hasil dari data yang diperoleh pada pra siklus, siklus I dan siklus II dari peningkatan kemampuan numerasi pada materi aritmatika dapat dipresentasikan pada Tabel 4.

Tabel 5 Data Peningkatan Kemampuan Numerasi Siswa Kelas VII C

\begin{tabular}{cccc}
\hline & $\begin{array}{c}\text { PRA } \\
\text { SIKLUS }\end{array}$ & $\begin{array}{c}\text { SIKLUS } \\
\text { I }\end{array}$ & $\begin{array}{c}\text { SIKLUS } \\
\text { II }\end{array}$ \\
\hline $\begin{array}{c}\text { Nilai } \\
\text { Tertinggi }\end{array}$ & 50 & 85 & 87 \\
\hline $\begin{array}{c}\text { Nilai } \\
\text { Terendah }\end{array}$ & 8 & 30 & 55 \\
\hline $\begin{array}{c}\text { Mencapai } \\
\text { KKM }\end{array}$ & 0 & 19 & 25 \\
\hline $\begin{array}{c}\text { Yaitu } \geq \\
60\end{array}$ & $0 \%$ & $62 \%$ & $74 \%$ \\
\hline
\end{tabular}

Berdasarkan Tabel 5 terlihat peningkatan kemampuan numerasi siswa kelas VII C MTs Negeri 1 Kuningan. Dari hasil tersebut terlihat adanya peningkatan kemampuan numerasi siswa pada materi aritmatika setelah diterapkan model pembelajaran kooperatif teknik teams games tournament (TGT) dari pra siklus, siklus I sampai dengan sklus II mengalami peningkatan. Data di atas memperlihatkan adanya peningkatan secara bertahap dan cukup memuaskan jika dibandingkan sebelum diterapkannya model pembelajaran kooperatif teknik teams games tournament (TGT). 


\section{PENUTUP}

Penerapan model pembelajaran kooperatif teknik teams games tournament (TGT) mennjukan peningkatan pada kemampuan numerasi materi aritmatika di kelas VII C MTs Negeri 1 Kuningan. Hal ini dapat dilihat dari hasil pra siklus sampai dengan siklus II, dimana pada pra siklus tidak ada siswa yang mencapai kriteria Ketuntasan Minimum (KKM) dengan nilai rata-rata 21. Siklus I mengalami peningkatan, dimana ada 19 siswa yang mencapai ketuntasan dengan rata-ratanya menjadi 62, tetapi ini belum mencapai keberhasilan kelas. Kemudian dilanjutkan pada siklus II dimana ada 25 siswa yang mencapai ketuntasan dan mendapatkan nilai rata-rata 74 .

\section{DAFTAR PUSTAKA}

Anam, F., Suteja, J. R., Septianto, A., Purnomo, A., \& Utami, Y. P. (2020). Improving the Numeracy Mathematics Ability: The Role of Abacus Learning Model. Journal of Physics: Conference Series, 1594(1). https://doi.org/10.1088/17426596/1594/1/012041

Apriani, R., Indaryanti, \& Hiltrimartin, C. (2014). Implementation of Cooperative Learning Model Teams Games Tournament ( Tgt ) on Learning Mathematics in Smp N 12 Palembang. SULE-IC, 743-749.
Aunio, P. (2019). Early Numeracy Skills Learning and Learning DifficultiesEvidence-based Assessment and Interventions. In Cognitive Foundations for Improving Mathematical Learning (1st ed., Vol. 5). Elsevier Inc. https://doi.org/10.1016/b978-0-12815952-1.00008-6

Baydar, A. (2020). Pre-Service Primary Teachers' Opinions on Team-GamesTournaments. International Education Studies, 14(1), 86. https://doi.org/10.5539/ies.v14n1p86

Cohen Kadosh, R., Dowker, A., Heine, A., Kaufmann, L., \& Kucian, K. (2013). Interventions for improving numerical abilities: Present and future. Trends in Neuroscience and Education, 2(2), 85-93.

https://doi.org/10.1016/j.tine.2013.04. 001

Department of Education and Skills. (2017). National Strategy: Literacy and Numeracy for Learning and Life 20112020 Interm Review. Interim Review, March, https://www.education.ie/en/Publicati ons/Education-

Reports/pub_ed_interim_review_liter acy_numeracy_2011_2020.PDF

Dowker, A. (2017). Interventions for Primary School Children With Difficulties in Mathematics. In Advances in Child 
Development and Behavior (1st ed., Vol. 53). Elsevier Inc. https://doi.org/10.1016/bs.acdb.2017. 04.004

Hwang, J., \& Ham, Y. (2021). Relationship between mathematical literacy and opportunity to learn with different types of mathematical tasks. Journal on Mathematics Education, 12(2), 199-222.

https://doi.org/10.22342/JME.12.2.13 625.199-222

Kementerian Pendidikan dan Kebudayaan. (2017). Materi Pendukung Literasi Numerasi. In Materi Pendukung Leterasi Numerasi: Vol. (1st ed., Issue). Kemendikbud.

Mercader, J., Miranda, A., Presentación, M. J., Siegenthaler, R., \& Rosel, J. F. (2018). Contributions of motivation, early numeracy skills, and executive functioning to mathematical performance. A longitudinal study. Frontiers in Psychology, 8(JAN), 111.

https://doi.org/10.3389/fpsyg.2017.02 375

Miller, T. (2018). Developing numeracy skills using interactive technology in a playbased learning environment. International Journal of STEM Education, $5(1)$. https://doi.org/10.1186/s40594-0180135-2
Mononen, R., Aunio, P., Koponen, T., \& Aro, $M$. (2014). A review of early numeracy interventions for children at risk in mathematics. International Journal of Early Childhood Special Education, 6(1), 25-54. https://doi.org/10.20489/intjecse.1435 5

Mulyani, R., Djumhana, N., \& Syaripudin, T. (2018). Penerapan Model Pembelajaran Kooperatif Team Games Tournament (Tgt) Untuk Meningkatkan Kemampuan Kerja Sama Siswa Sekolah Dasar. Jurnal Pendidikan Guru Sekolah Dasar, 3(2), 38-45.

https://doi.org/10.17509/jpgsd.v3i2.14 067

OECD. (2019). Programme for international student assessment (PISA) results from PISA 2018. Oecd, 1-10. https://www.oecdilibrary.org/education/pisa-2018results-volume-iii_bd69f805en\%0Ahttps://www.oecdilibrary.org//sites/bd69f805en/index.html?itemld=/content/compo nent/bd69f805-en\#fig86

Ramadhani, W. P., \& Indrawati, A. G. (2020). Penerapan Model Pembelajaran Kooperatif Tipe Teams Games Tournaments (Tgt) Dengan Media Pembelajaran Ultpygo Untuk Meningkatkan Hasil Belajar 
Matematika Siswa. JIPMat, 5(2), 211230.

https://doi.org/10.26877/jipmat.v5i2.5 480

Rizki, L. M., \& Priatna, N. (2019). Mathematical literacy as the 21st century skill. Journal of Physics: Conference Series, 1157(4). https://doi.org/10.1088/17426596/1157/4/042088

Salam, A., Hossain, A., \& Rahman, S. (2015). Teams Games Tournaments ( TGT ). Cooperative Technique for Learning Mathematics in Secondary Schools in Bangladesh. Malaysian Online Journal of Educational Technology, 3(3), 271-287. https://doi.org/10.4471/redimat.2015. 1519

Sidi, R. R., \& Yunianta, T. N. H. (2018). Meningkatakan Hasil Belajar Matematika Siswa SMP Kelas VII Pada Materi Aljabar Dengan Menggunakan Strategi Joyful Learning. 5(1), 39-50.

Veloo, A., Md-Ali, R., \& Chairany, S. (2016). Using cooperative teams-gametournament in 11 religious school to improve mathematics understanding and communication. Malaysian Journal of Learning and Instruction, 13(2), 97-123. https://doi.org/10.32890/mjli2016.13. 2.4 